\title{
HOW DOES TOP MANAGEMENT TEAM DIVERSITY MATTER IN ABRUPTLY DYNAMIC ENVIRONMENTS?
}

\author{
Wein-Hong $\mathrm{CHEN}^{1^{*}}$, Yi-Yuan LIU ${ }^{2}$ \\ ${ }^{1}$ Department of Business Administration, National Dong Hwa University, \\ Hualien, Taiwan \\ ${ }^{2}$ Department of Marketing and Distribution Management, \\ Oriental Institute of Technology, Taipei, Taiwan
}

Received 07 May 2017; accepted 14 September 2018

\begin{abstract}
This study seeks to investigate how top management team (TMT) diversity as a doubleedged sword influences a firm's resilient performance in abruptly dynamic environments and how TMT group longevity moderates this relationship. Abruptly dynamic environment is characterized by low-frequency, substantial magnitude, and high-degree irregularity of change. Utilizing 168 listed electronics firms in Taiwan as the sample, this study incorporated the context of the 2008 global financial crisis as a naturally quasi-experimental setting and adopted a less investigated performance metric, firm resilient performance, to investigate how the two most researched types of TMT job-related diversity (i.e., educational and functional diversity) influence firm resilience in such environments. The results suggest that in abruptly dynamic environments, TMT job-related diversity negatively influences firms' resilient performance, and TMT longevity significantly moderates this relationship. This study makes unique contributions to the upper-echelons literature by investigating the effect of TMT diversity in a naturally quasi-experimental setting featuring abrupt environmental dynamism.
\end{abstract}

Keywords: dynamic environments, global financial crisis, resilient performance, top management team diversity, uncertainty, upper echelons theory.

JEL Classification: E39, L25, G01, M14, D89, M19.

\section{Introduction}

The last several decades have witnessed rapid growth in top management team (TMT) research (Hambrick, 2007; Homberg \& Bui, 2013; Li \& Lo, 2017). Among this research, the influence of TMT diversity on firm performance has attracted considerable attention. Empirical scrutiny has led to the conclusion that TMT diversity is a double-edged sword (Homberg \& Bui, 2013; Jarzabkowski \& Searle, 2004; Parola, Ellis, \& Golden, 2015; Prasad

\footnotetext{
${ }^{\star}$ Corresponding author. E-mail: weinhong@gms.ndhu.edu.tw
} 
\& Junni, 2017). TMT diversity leads to the use of broad sources of information, which helps executives perceive more opportunities or develop alternative solutions than would otherwise be the case (Hough \& White, 2003; Yoon, Kim, \& Song, 2016). Whereas, TMT diversity also induces conflict and impedes communication among top executives (Carpenter, 2002; Prasad \& Junni, 2017). To date, the empirical evidence concerning the TMT diversity-firm performance relationship in dynamic environments is inconsistent (for comprehensive reviews, please refer to Certo, Lester, C. M. Dalton, \& D. R. Dalton, 2006; Homberg \& Bui, 2013).

The inconsistency in the empirical evidence leads to two questions. The first question is whether certain types of TMT diversity play more critical roles in dynamic environments than other types of TMT diversity (Díaz-fernández, González-rodríguez, \& Simonetti, 2016; Naranjo-Gil, Hartmann, \& Maas, 2008; Webber \& Donahue, 2001). Naranjo-Gil et al. (2008) suggest that job-related TMT characteristics (e.g., education, function, and tenure) are more critical than demographic characteristics (e.g., age and sex) when facing environmental dynamism. The second question is related to the characteristics of environmental dynamism. Environmental dynamism varies depending on "frequency of change," "magnitude of change," and "irregularity of change" (Hauschild, Knyphausen-Auseß, \& Rahmel, 2011, p. 423). In abruptly dynamic environments, which are characterized by low frequency, substantial magnitude, and high-degree irregularity of change, rapid and effective strategic decision making to address the irregularity of change is particularly crucial (Eisenhardt, 1989; Hauschild et al., 2011; Judge \& Miller, 1991). However, irregularity of change increases the difficulty of collectively making expeditious strategic decisions because decision makers experience "the anxiety of high-stakes decision making" (Eisenhardt, 1989, p. 544). Although TMT job-related diversity has been proved crucial in dynamic environments (Naranjo-Gil et al., 2008), how TMT job-related diversity influences firms' resilience in a distinct type of dynamic environment (e.g., abruptly dynamic environments) remained underexplored (Sabatino, 2016; Weick \& Sutcliffe, 2007).

Motivated by this gap in the literature, this study investigated how the two most researched types of TMT job-related diversity (i.e., educational and functional diversity) influence firms' resilience in abruptly dynamic environments. The research question facilitated investigating the dual effect of TMT diversity. This paper proposes that in situations of abrupt environmental dynamism, top executives' anxiety about high-risk decision making increases conflict occurrence when a TMT is diversified (Pelled, Eisenhardt, \& Xin, 1999). Therefore, it is likely that the negative effect of TMT diversity prevails over the positive effect of TMT diversity in such environments. However, the negative effect of TMT diversity is likely to be weakened if top executives have familiarized themselves with diversified viewpoints because of high group longevity (Pelled et al., 1999).

This study incorporated the context of the 2008 global financial crisis as a naturally quasiexperimental setting to investigate the role of TMT diversity in abruptly dynamic environments. The proposed relationships were tested on a sample of 168 electronics firms in a newly industrialized economy. The global financial crisis compelled these firms to undergo sharp changes in the macro, industrial, and competitive environments and tested each firm's capacity to withstand the resulting global economic turmoil (Bricongne, Fontagne, Gaulier, Taglioni, \& Vicard, 2012; Sabatino, 2016; Van Geyt, Van Cauwenberge, \& Vander Bauwhede, 2013). 
This paper offers several unique contributions to the relevant upper-echelon literature. First, to the best of the authors' knowledge, this study was the first to investigate the effect of TMT diversity in a naturally quasi-experimental setting that features abrupt environmental dynamism. This research revealed that the negative effect of TMT diversity is likely to outweigh the positive effect of TMT diversity in abruptly dynamic environments. This paper provides an alternative explanation for the previous inconsistent empirical evidence concerning the effect of TMT diversity in dynamic environments (Homberg \& Bui, 2013). Second, this paper highlights the crucial role that TMT group longevity plays in environments featuring abrupt dynamism. Previous studies have paid limited attention to TMT group longevity (e.g., Boerner, Linkohr, \& Kiefer, 2011). This study's empirical results highlight the distinctive moderating role that TMT group longevity plays in influencing the TMT diversity-resilient performance relationship. Third, this study investigated the role of TMT diversity based on firms that operate in a newly industrialized economy and that are vulnerable to global shocks. This paper supplements the existing understanding of TMT diversity, which has focused on firms operating in advanced economies.

\section{Theoretical background}

TMT diversity, defined as the degree to which a firm's top executives differ in their characteristics or experience, is a critical construct in upper echelons theory research (Lee \& Park, 2006). The central argument of upper echelons theory is that top executives' experience and characteristics are crucial predictors of organizational outcomes (Hambrick \& Mason, 1984). Top executives interpret strategic environments based on their cognition, which is shaped by their characteristics and experience. The interpretation of strategic environments affects strategic choices and resource allocation decisions, which eventually influence organizational outcomes (Mousa \& Chowdhury, 2014; Hambrick, 2007).

Murray (1989), a pioneer of empirical investigation into the role of TMT diversity in different environments, reveals that TMT diversity plays a more substantial role in dynamic environments than in stable environments. Later empirical results suggest that TMT diversity is a double-edged sword that affects firm performance both positively and negatively in dynamic environments (Certo et al., 2006; Jarzabkowski \& Searle, 2004; Homberg \& Bui, 2013). The positive impact of TMT diversity has frequently been discussed in the management literature based on social psychological views, emphasizing the value of diverse cognitive resources (Bantel \& Jackson, 1989; Carpenter, 2002; Kor, 2003; Yoon et al., 2016). A diverse cognitive base of a TMT enhances the firm's collective managerial capacity to collect and process information related to the environment, and it helps to avoid biases caused by individual managers' incomplete views of the environment (Eggers \& Kaplan, 2013). Alternatively, the negative effect of TMT diversity has stemmed from the relational conflict view in the organizational demography literature (Bantel \& Jackson, 1989; Carpenter, 2002; Pelled, 1996; Pelled et al., 1999; Prasad \& Junni, 2017). TMT diversity increases interpersonal conflicts, which is dysfunctional to collective decision making and in turn impedes organizational performance (Carpenter, 2002; H. Li \& J. Li, 2009; Prasad \& Junni, 2017). In addition to the double-edged-sword effect of TMT diversity, studies have suggested that 
various types of TMT diversity play dissimilar roles in dynamic environments. Naranjo-Gil et al. (2008) suggests that job-related types of TMT diversity (e.g., education and function) are more critical than demographic types of TMT diversity (e.g., age and gender) in dynamic environments. Their study indicates that job-related TMT diversity, which represents a repertoire of cognitive resources to handle complex circumstances, has a positive and significant influence on firm performance outcomes in dynamic environments, whereas, nonjob-related TMT diversity has no significant effect on firm performance.

Executive perceptions of environmental uncertainty are also contingent on the nature of environmental dynamism (Hauschild et al., 2011). For example, abrupt environmental dynamism, which is characterized by a high irregularity of change, increases executives' perceived uncertainty (Hauschild et al., 2011) and anxiety from high-stakes decision making (Eisenhardt, 1989). This study investigated the effect of the two most widely researched types of TMT job-related diversity - TMT educational diversity and TMT functional diversity (Homberg \& Bui, 2013; Yang \& Wang, 2014) - on firms' resilient performance in abruptly dynamic environments (Weick \& Sutcliffe, 2007).

\section{Hypotheses}

\subsection{TMT educational diversity and firm resilient performance in abruptly dynamic environments}

TMT educational diversity refers to the diversification of curricular backgrounds among top executives (Hambrick, Cho, \& Chen, 1996). Executives' curricular background shapes managerial cognition, which affects interpretation of strategic situations and environments (Eggers \& Kaplan, 2013). Educational training develops managerial mental templates that affect how executives process information (Finkelstein \& Hambrick, 1996; Hambrick \& Mason, 1984; Hitt \& Tyler, 1991). Milliken and Martins (1996) suggest that a TMT that comprises executives who are diverse in their educational training tends to embrace diverse mental templates, which increases its collective capacity to search for and process information.

Abrupt environmental dynamism imposes time constraints on making win-or-lose decisions (Eisenhardt, 1989; Prasad \& Junni, 2017; Yoon et al., 2016). Decision making in such environments requires evaluating multiple problems and quickly interpreting divergent realtime information (Kauer, Waldeck, \& Schäffer, 2007). Executives with distinctive educational training may interpret real-time information in a disparate manner. In abruptly dynamic environments, although TMT educational diversity may enhance a TMT's capacity to collect and process real-time information, time pressures are likely to impede effective discussion of relevant information (Parola et al., 2015; Prasad \& Junni, 2017). Consequently, the negative effect of TMT educational diversity is likely to outweigh the positive effect of this type of diversity on a firm's resilient performance in abruptly dynamic environments. Thus, the following hypothesis is proposed:

H1. In abruptly dynamic environments, TMT educational diversity is likely to negatively influence a firm's resilient performance. 


\subsection{TMT functional diversity and firm resilient performance in abruptly dynamic environments}

Functional background refers to the functional areas to which an executive has been exposed. Functional exposure develops a manager's knowledge, skill sets, and competence in specific functional areas (e.g., manufacturing, logistics, or marketing) (Hambrick \& Mason, 1984). TMT functional diversity reflects TMT's diverse functional expertise and shapes the breadth of top managers' perception of strategic events (Heavey \& Simsek, 2017). A TMT that is characterized by a diverse functional background possesses more multifarious task-relevant knowledge and distinctive skills in processing functional-related information than a TMT that lacks such a diverse functional background (Boerner et al., 2011; Cannella Jr., Park, \& Lee, 2008; Kauer et al., 2007).

Pelled et al. (1999) suggest that functional background differences are key sources of task conflict, especially in complex environments. Abrupt environmental dynamism confronts a TMT with major challenges in addressing organizational issues that involve multiple functional decisions (Stieglitz, Knudsen, \& Becker, 2016). A TMT that has a diverse functional background may struggle with contrasting functional viewpoints. For example, when facing abrupt environmental dynamism, an executive whose background is in finance may propose to downsize, whereas another executive whose background is in marketing may propose market expansion as a solution.

Additionally, abrupt environmental dynamism imposes strict time constraints on highstakes decision making, which increases the anxiety level among top executives (Prasad \& Junni, 2017). High anxiety levels among top executives might result in severe task conflicts among functionally diversified executives and might thus magnify the negative effect of TMT functional diversity on a firm's resilient performance in such environments. Thus, the following hypothesis is proposed:

H2. In abruptly dynamic environments, TMT functional diversity is likely to negatively influence a firm's resilient performance.

\subsection{Moderating effect of TMT group longevity}

Although TMT diversity is a double-edged sword for firm performance outcomes (Certo et al., 2006; Jarzabkowski \& Searle, 2004; Homberg \& Bui, 2013), the negative effect of TMT diversity is likely to be weakened when team members work with each other for long time (Harrison, Price, \& Bell, 1989). Group longevity, defined as "the length of time group members have spent working together", reflects team familiarity and development of team routines (Pelled et al., 1999, p. 9). The longer group members work together, the more likely they will be familiar with each other's cognitive variety, and the more likely team communication routines will be developed. Development of communication routines facilitates effective discussions among executives and increases speed of decision making (Eisenhardt, 1989). The development of communication routines also helps harness diversity in a team (Kor, 2003).

In upper echelons research, the role of TMT group longevity has been underexplored to date; whereas, TMT group longevity may influence how TMT diversity matters in abruptly dynamic environments. Abrupt environmental dynamism imposes tight time constraint in 
making high stakes decisions in order to deal with the sudden shock, and a TMT needs to interpret diverse real-time information in a timely manner (Kauer et al., 2007). As the aforementioned, executives with diverse educational background may interpret real-time environmental information in a disparate way. Development of team communication routines, as reflected by higher TMT group longevity, will stimulate meaningful discussions about how the real-time information can be transformed into a range of alternative solutions. Hence, although the negative effects of TMT educational diversity is likely to outweigh the positive effects of such diversity in abruptly dynamic environments, TMT group longevity may weaken the negative relationship between TMT educational diversity and a firm's resilient performance. The following hypothesis is thus proposed:

H3. In abruptly dynamic environments, the negative effect of TMT educational diversity on a firm's resilient performance is likely to be weakened when TMT group longevity is high.

TMT group longevity may also moderate the relationship between TMT functional diversity and a firm's resilient performance. When a TMT needs to deal with organizational issues that involve multiple functions in an abruptly dynamic environment, functionally-diversified executives are likely to propose distinctive alternatives to solve complex organizational issues that involve multiple functional problems (Cannella Jr. et al., 2008; Heavey \& Simsek, 2017; Kauer et al., 2007). Functional background differences are key sources of task conflicts (Pelled et al., 1999), and abrupt environmental dynamism may augment the occurrence of task conflicts because of the likely high anxiety level among top executives. However, if TMT members have worked with each other for long time, the development of team communication routines may settle certain task conflicts. For example, a firm may set up priority rules to help facilitate decision making in dynamic environments (Eisenhardt \& Sull, 2001). Therefore, the negative effect of TMT functional diversity on a firm's resilient performance is likely to be weakened when TMT group longevity is high. The following hypothesis is thus proposed:

H4. In abruptly dynamic environments, the negative effect of TMT functional diversity on a firm's resilient performance is likely to be weakened when TMT group longevity is high.

\section{Methods}

\subsection{Samples and sources of data}

Listed electronics firms in Taiwan were sampled in this study to test the proposed hypotheses. Taiwanese electronic firms play a vital role in the global electronics industry (E. Lin, T. Lin, \& B. Lin, 2010) and are highly dependent on the global market. This high degree of dependence has rendered Taiwanese electronics firms vulnerable to global environmental shocks. The original sample included 192 listed firms in three subcategories of the electronics industry. The three subcategories were noticeably affected by the global financial crisis. Among the 192 listed firms in the original sample, four firms lacked comprehensive performance outcome data in 2005-2011 and were dropped from the sample; another 11 firms were excluded from the sample due to lack of data regarding their spending on research and development (R\&D); and nine firms did not provide comprehensive TMT background data and were thus also dropped from the sample. The final sample included 168 firms for the analysis and model estimation. 
This study set 2008 as the base year for its analyses because the global financial crisis began in 2008. The world economic outlook dataset provided by the International Monetary Fund (2018) indicates that the global economy underwent its most severe postwar recession during the period following 2008. The growth rate of global real gross domestic product (GDP) (i.e., the inflation-adjusted value of GDP) slumped from a peak of 5.6\% in 2007 to $-0.1 \%$ in 2009 , rebounded to $5.4 \%$ in 2010 , and stabilized at $3 \%-4 \%$ afterward. Taiwan's real GDP growth also experienced a sudden decline and recovery during this period. The sales growth of the electronics industry in Taiwan experienced both a steep decline and a drastic increase during this period, slumping from $8.8 \%$ in 2007 to $-11.9 \%$ in 2009 before rebounding to over 30\% in 2010 (Taiwan Ministry of Economic Affairs, 2018). After the 2008 global financial crisis, fluctuation occurred in Taiwan's economy and Taiwan's electronics industry. Figure 1 illustrates the trend of growth in world and Taiwanese real GDP alongside Taiwan's electronics industry sales from 2001 to 2017. This trend confirms that the context of the 2008 global financial crisis featured abrupt environmental dynamism, thus serving as a naturally quasi-experimental setting. Therefore, the sample data provided a suitable business context for this study.

TMT background and firm performance data were acquired from various sources. TMT background information was collected from the 2008 annual reports of the sample firms. Firm-level longitudinal performance data were obtained from the Taiwan Economic Journal database, which is a widely used data source in the Asia-Pacific region (Chung \& Luo, 2013).

\subsection{Measures}

\subsubsection{Dependent variable: firm resilient performance}

Firm resilient performance is a less investigated performance metric in the management field (Sabatino, 2016). Change in ROE was used to reflect resilient performance, which indicates how effectively an electronics firm performed during the global financial crisis. ROE, the ratio of net income to shareholders' equity, was selected as the primary indicator of performance in the context of global financial crisis because ROE reflects a firm's capability to

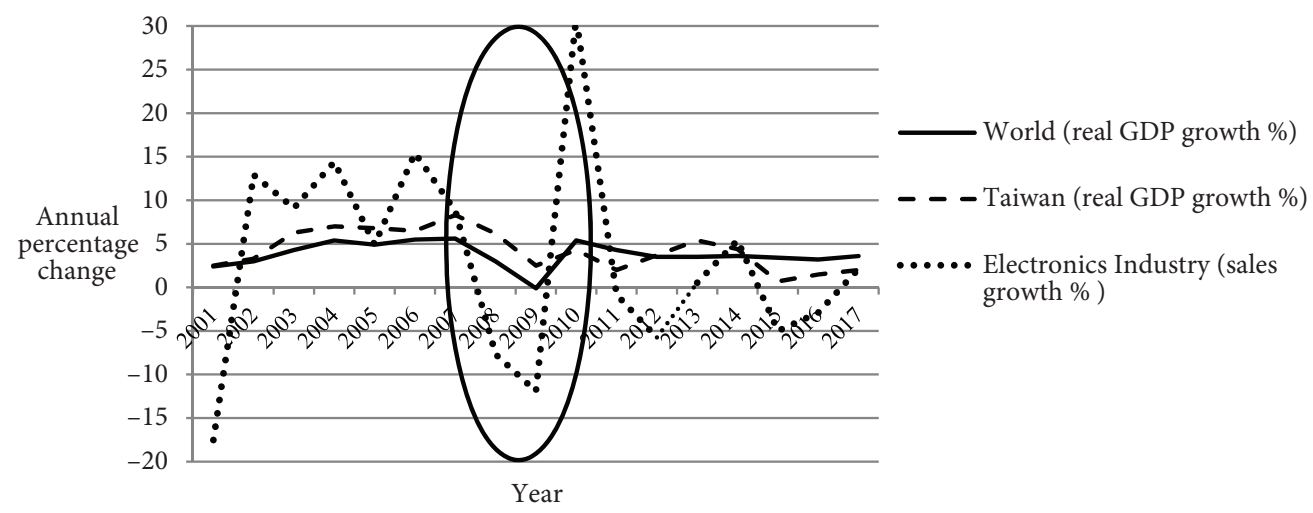

Figure 1. Illustration of the abrupt environmental dynamism induced by the 2008 global financial crisis - impacts on the world's economy, Taiwan's economy, and electronics industry in Taiwan 
generate returns for shareholders by appropriating the resources available, including restructuring debts and recapitalizing. To reflect how effectively a firm recovered from the global financial crisis, the change in ROE was measured by subtracting the average 3 -year ROE prior to 2008 (i.e., 2005-2007) from the average 3-year ROE after 2008 (i.e., 2009-2011). In addition to the change in ROE, the changes in return on assets (ROA) and return on sales (ROS) were also calculated as a robustness check on the empirical results.

\subsubsection{Independent variables: TMT educational diversity and TMT functional diversity}

TMT was defined as the group of executive ranked vice president and above (for a comprehensive review, please refer to Carpenter, Geletkanycz, \& Sanders, 2004). Although some previous upper echelons studies define the TMT as executives who also serve on the boards of directors (Finkelstein \& Hambrick, 1996), this study does not follow this definition because in the business context of Taiwan, the composition of a board is distinctive from the composition of a TMT. The TMT size of sample firms is in the range of 1 to 19, with an average of 5.15. The two types of diversity were operationalized as composite measures generated from the following subsequent procedures. Factual information regarding top executives' educational and functional experience was collected from the sample firms' 2008 annual reports. This factual information was subsequently coded following the method that Hambrick et al. (1996) proposed for categorizing educational and functional backgrounds. The categorization of educational background proposed by Hambrick et al. (1996) includes eight categories: engineering, science, business administration, economics, liberal arts, law, business-other-than-administration, and other subjects. In considering Taiwan's specific business context, two categories were added for executives' educational background: medical or biological technology and international relations. The categorization of functional background proposed by Hambrick et al. (1996) covers 16 categories. On the basis of the categorization proposed by Hambrick et al. (1996), the following 16 categories were established to reflect the functional backgrounds for Taiwan's business context: general management, secretary, production, marketing, sales/customer service, public relations, personnel/human resources, R\&D, finance/treasurer, accounting/controller, information system, engineering, legal, warehousing, purchasing, and other. The coded TMT educational and functional data for each firm were used to calculate a Herfindal-Hirschman index to reflect firm-level TMT educational diversity and TMT functional diversity (Hambrick et al., 1996). The HerfindalHirschman index was calculated as follows:

$$
H=1-\sum_{j=1}^{n} p_{j}^{2},
$$

where $H$ is the TMT diversity measure and $p$ is the percentage of the number of executives in the team with backgrounds in the jth category in relation to the aggregate counts of educational background or functional experience in the TMT.

\subsubsection{Moderating variable: TMT group longevity}

Following the measurement of group longevity utilized by Pelled et al. (1999), TMT group longevity was calculated by averaging the individual duration of service of all members in each 
TMT up to 2008. The mean was used to obtain the estimates of how long these TMT members had worked together, interacted with each other, and shared experiences with one another.

\subsubsection{Control variables}

This study included several firm-level controls that have often been controlled for in the firm performance literature (Daniel, Lohrke, \& Fornaciari, 2004). Firm size, measured as the natural logarithm of total assets in 2008, was controlled for because large firms tend to have relatively more resources to deal with environmental uncertainty, which in turn may influence their resilient performance (Chau, Thomas, Clegg, \& Leung, 2012). Public listing age, measured as the natural logarithm of the number of years from public listing to 2008, was controlled for because listed firms can obtain access to external resources, which might influence a firm's resilient performance (Demsetz \& Lehn, 1985). Additionally, firms' technological competence was controlled for because firm technological competence has been demonstrated to be highly related to firm performance (Beneito, 2006; A. Bharadwaj, S. Bharadwaj, \& Konsynski, 1999; Nelson, 1982). This research captured electronic firms' technological competence by measuring R\&D intensity (Tan \& Mahoney, 2005). R\&D intensity was calculated as the ratio of a firm's reported R\&D spending to its sales (Chang, Wang, Hung, \& Sun, 2015; Hambrick \& MacMillan, 1985). Taiwanese regulations require public firms to disclose their R\&D spending in their annual reports. Business risk tolerance, measured as the net worth ratio in 2008, was also controlled for. Business risk tolerance reflects a preference for innovative activities (Covin \& Slevin, 1989). Corporations that prefer innovative activities tend to be in a more favorable position to compete in a dynamic environment (Davis, Bell, Payne, \& Kreiser, 2010).

In addition to these firm-level controls, this study also controlled for two TMT characteristics. TMT size, measured as the number of executives comprising a TMT, was controlled for because large TMTs may possess greater information-processing capacities, which may influence resilient performance (Certo et al., 2006). This study also controlled for a dummy variable representing whether a TMT includes executives who have international experience. The dummy variable assumed a value of one for a TMT that includes executives who have worked or pursued academic degrees abroad and a value of zero for a TMT that lacks internationally experienced executives. A TMT that includes executives with international experience tends to have a global mindset, which may have influenced the respective firm's strategic actions in response to the global financial crisis, thereby influencing the firm's resilient performance (Sambharya, 1996). Subindustry dummies were also controlled for because three subindustries of the electronics industry (i.e., computer and peripheral equipment manufacturing, communication technology manufacturing, and electronic solution product manufacturing) were included in the sample firms, and the global financial crisis may have imposed different effects on the distinct subindustries (Bricongne et al., 2012; Van Geyt et al., 2013).

\section{Findings and discussion}

Table 1 provides descriptive statistics and correlation coefficients for the variables included in this study. As Table 1 shows, the mean of ROE resilient performance is -5.26 , and the 
standard deviation is 31.11 . The descriptive statistics suggest that after the global financial crisis on average, the sample firms did not return to their performance levels before the financial crisis. However, substantial variation in these sample firms' resilient performance was observed. The findings support our decision to investigate whether TMT diversity helps some firms to be more resilient than others in this research context. All variables were standardized, and moderated hierarchical regression analyses were conducted to test the hypotheses. Standardization minimizes the threat of multicollinearity and facilitates the explanation of interaction effects (Aiken \& West, 1991). The potential problem of multicollinearity was further mitigated by generating variance inflation factors (VIFs) for the regression coefficients. The VIFs, ranging from 1.05 to 3.17 , were considerably lower than the recommended cut-off of 10 , suggesting that multicollinearity did not threaten the validity of the coefficient estimates (Neter, Wasserman, \& Kutner, 1985).

Table 1. Means, standard deviations, and correlations ${ }^{\text {ab }}$

\begin{tabular}{|c|c|c|c|c|c|c|c|c|c|c|c|c|}
\hline & Mean & SD & 1 & 2 & 3 & 4 & 5 & 6 & 7 & 8 & 9 & 10 \\
\hline $\begin{array}{l}\text { 1. ROE Resil- } \\
\text { ient Perfor- } \\
\text { mance }\end{array}$ & -5.26 & 31.11 & 1.00 & & & & & & & & & \\
\hline $\begin{array}{l}\text { 2. TMT edu- } \\
\text { cational diver- } \\
\text { sity }\end{array}$ & 0.33 & 0.24 & -0.13 & 1.00 & & & & & & & & \\
\hline $\begin{array}{l}\text { 3. TMT func- } \\
\text { tional diver- } \\
\text { sity }\end{array}$ & 0.43 & 0.26 & -0.20 & 0.07 & 1.00 & & & & & & & \\
\hline $\begin{array}{l}\text { 4. TMT group } \\
\text { longevity } \\
\text { (natural log) }\end{array}$ & 4.05 & 0.86 & -0.16 & -0.08 & -0.04 & 1.00 & & & & & & \\
\hline 5. Firm size & 14.85 & 1.45 & -0.08 & 0.24 & 0.09 & 0.00 & 1.00 & & & & & \\
\hline $\begin{array}{l}\text { 6. Public list- } \\
\text { ing age (natu- } \\
\text { ral log) }\end{array}$ & 4.36 & 0.56 & 0.13 & 0.03 & -0.03 & 0.08 & 0.54 & 1.00 & & & & \\
\hline $\begin{array}{l}\text { 7. Techno- } \\
\text { logical compe- } \\
\text { tence }\end{array}$ & 6.01 & 5.75 & -0.02 & -0.06 & 0.11 & 0.03 & -0.31 & -0.11 & 1.00 & & & \\
\hline $\begin{array}{l}\text { 8. Business } \\
\text { risk tolerance }\end{array}$ & 60.16 & 16.19 & 0.01 & -0.13 & -0.01 & 0.24 & -0.41 & -0.11 & 0.35 & 1.00 & & \\
\hline 9. TMT size & 5.04 & 4.92 & -0.02 & 0.28 & 0.16 & -0.06 & 0.73 & 0.35 & -0.17 & -0.36 & 1.00 & \\
\hline $\begin{array}{l}\text { 10.TMT with } \\
\text { international } \\
\text { experience }\end{array}$ & 0.40 & 0.49 & -0.11 & 0.09 & 0.39 & -0.02 & 0.28 & 0.15 & 0.11 & -0.05 & 0.35 & 1.00 \\
\hline
\end{tabular}

Note: $n=168$.

${ }^{\text {a } C o r r e l a t i o n s ~ a b o v e ~} 0.12$ are significant at $p<.05$ level.

$\mathrm{b}$ The means and standard deviations reflect the original data structure. Original data were standardized for correlation and moderated hierarchical regression analyses. 
Table 2 presents the results of the moderated hierarchical regression model. Model 1, the baseline model, comprises the control variables. The empirical result of this study indicates that firm size negatively influences the resilient performance of a firm in abruptly dynamic environments. Although large firms are generally considered to have more financial slack to stabilize themselves in times of distress than smaller firms (Dolmans, van Burg, Reymen, \& Romme, 2014), the result of this study implies that when facing sudden environmental

Table 2. Results of regression analysis predicting ROE resilient performance

\begin{tabular}{|c|c|c|c|c|c|c|c|c|c|}
\hline \multirow[b]{3}{*}{ Variable } & \multicolumn{9}{|c|}{ Dependent variable: ROE resilient performance } \\
\hline & \multicolumn{3}{|c|}{ Model 1} & \multicolumn{3}{|c|}{ Model 2} & \multicolumn{3}{|c|}{ Model 3} \\
\hline & $\beta$ & t-value & & $\beta$ & t-value & & $\beta$ & t-value & \\
\hline \multicolumn{10}{|l|}{ Control variables } \\
\hline Firm size & -0.31 & -2.33 & * & -0.28 & -2.12 & * & -0.30 & -2.40 & * \\
\hline Public listing age & 0.29 & 3.08 & $* *$ & 0.27 & 2.96 & $* *$ & 0.27 & 3.11 & $* *$ \\
\hline $\begin{array}{l}\text { Technological com- } \\
\text { petence }\end{array}$ & -0.05 & -0.58 & & -0.04 & -0.50 & & -0.07 & -0.88 & \\
\hline $\begin{array}{l}\text { Business risk } \\
\text { tolerance }\end{array}$ & -0.03 & -0.29 & & 0.02 & 0.20 & & -0.02 & -0.23 & \\
\hline TMT size & 0.13 & 1.11 & & 0.14 & 1.23 & & 0.13 & 1.22 & \\
\hline $\begin{array}{l}\text { TMT with interna- } \\
\text { tional experience }\end{array}$ & -0.11 & -1.27 & & -0.04 & -0.47 & & -0.01 & -0.11 & \\
\hline Sub-industry 1 & 0.34 & 1.76 & $\dagger$ & 0.33 & 1.79 & $\dagger$ & 0.35 & 2.01 & * \\
\hline Sub-industry 2 & 0.10 & 0.50 & & 0.20 & 0.99 & & 0.25 & 1.36 & \\
\hline \multicolumn{10}{|l|}{ Direct effects } \\
\hline $\begin{array}{l}\text { TMT educational } \\
\text { diversity }\end{array}$ & & & & -0.12 & -1.46 & $\dagger$ & -0.12 & -1.65 & $\dagger$ \\
\hline $\begin{array}{l}\text { TMT functional } \\
\text { diversity }\end{array}$ & & & & -0.18 & -2.22 & * & -0.23 & -3.01 & $* *$ \\
\hline $\begin{array}{l}\text { TMT group lon- } \\
\text { gevity }\end{array}$ & & & & -0.19 & -2.45 & $*$ & -0.15 & -1.94 & * \\
\hline \multicolumn{10}{|l|}{ Interaction effects } \\
\hline $\begin{array}{l}\text { TMT educational } \\
\text { diversity } \times \text { TMT } \\
\text { group longevity }\end{array}$ & & & & & & & 0.11 & 1.69 & $\dagger$ \\
\hline $\begin{array}{l}\text { TMT functional } \\
\text { diversity } \times \text { TMT } \\
\text { group longevity }\end{array}$ & & & & & & & 0.32 & 4.10 & $* * *$ \\
\hline Constant & -0.17 & -1.16 & & -0.20 & -1.38 & & -0.21 & -1.52 & \\
\hline F-value & & 2.01 & $*$ & & 2.67 & $* *$ & & 4.32 & $* * *$ \\
\hline $\mathrm{R}^{2}$ & & 0.09 & & & 0.16 & & & 0.27 & \\
\hline Adjusted $\mathrm{R}^{2}$ & & 0.05 & & & 0.10 & & & 0.21 & \\
\hline
\end{tabular}

Note: $n=168 .{ }^{\dagger} p<.10,{ }^{*} p<.05,{ }^{* *} p<.01,{ }^{* *} p<.001$, two-tailed tests. 
shocks, firms with more financial slack may encounter conflicts associated with the allocation of such financial resources (Mousa \& Chowdhury, 2014) or that financial slack may mask underlying problems and induce misfit behaviour in the changing environment (Dolmans et al., 2014). The result also indicates that public listing age positively influences a firm's resilient performance, which implies the importance of external financial resources in such environments.

Model 2 comprises the main effects of independent variables and the moderator. Model 3 is the full model, comprising all main and interaction effects. The full model is statistically significant $(p<.001)$. The adjusted R-square of the full model is 0.21 , which is comparable with prior studies in the strategy field (Auh \& Menguc, 2005).

The results support Hypothesis 1, which argues that TMT educational diversity is negatively related to a firm's resilient performance. The coefficient of TMT educational diversity is negative and marginally significant $(\beta=-0.12 ; p<.1)$. The results likewise support Hypothesis 2 , which also suggests a negative relationship between TMT functional diversity and resilient performance of a firm. The coefficient for TMT functional diversity is negative and significant $(\beta=-0.23 ; p<.01)$. Additionally, Hypotheses 3 and 4 were posited to suggest that when TMT group longevity is greater, the negative effect of TMT educational or functional diversity on a firm's resilient performance is likely to be weakened. The results indicate that TMT group longevity significantly moderates the functional diversity-resilient performance relationship $(p<.001)$ and that it moderates the educational diversity-resilient performance relationship to a marginally significant degree $(p<.1)$.

Simple slopes of the interaction terms were plotted to further interpret the significance of these interaction effects, as suggested by Aiken and West (1991). As illustrated in Figure 2, the relationship between TMT educational diversity and resilient performance is significant and negative when TMT group longevity is low (gradient of slope $=-0.24, p<.05$ ). When TMT group longevity is high, the relationship between TMT educational diversity and resilient performance is not significantly different from zero. As expected, when TMT group longevity is high, the negative effect of TMT educational diversity on a firm's resilient performance is likely to be weakened. Thus, the results supported Hypothesis 3. In addition, Figure 3 illustrates how resilient performance is influenced by the interaction between TMT functional diversity and group longevity. As exhibited in Figure 3, the relationship between TMT functional diversity and resilient performance is positive and marginally significant when TMT group longevity is high (gradient of slope $=0.2, p<.1$ ), and the relationship between TMT functional diversity and resilient performance is significant and negative when TMT group longevity is low (gradient of slope $=-0.44, p<.001$ ). Hypothesis 4 suggests that the negative effect of TMT functional diversity on resilient performance is weakened when TMT group longevity is high. The results indicate that TMT group longevity performs a substantial moderating role in overturning the negative association between TMT functional diversity and a firm's resilient performance. Additionally, Figures 2 and 3 indicate that when TMT job-related diversity and group longevity are both low, firms' resilient performance is likely to be highest. The findings imply that a newly formed TMT with homogeneous educational or functional experience works most effectively in abruptly dynamic environments. The group formation literature suggests that team tenure has a curvilinear effect on 
team psychological safety climate, defined as "shared perceptions that the team is safe for interpersonal risk taking," which in turn influences team performance (Koopmann, Lanaj, Wang, Zhou, \& Shi, 2016, p. 940). A newly formed team, including a TMT, is likely to focus on the development of trust and the creation of a common group identity, which facilitate positive perceptions of similarities among team members (Koopmann et al., 2016; McKnight, Cummings, \& Chervany, 1998). In abruptly dynamic environments, a TMT must make

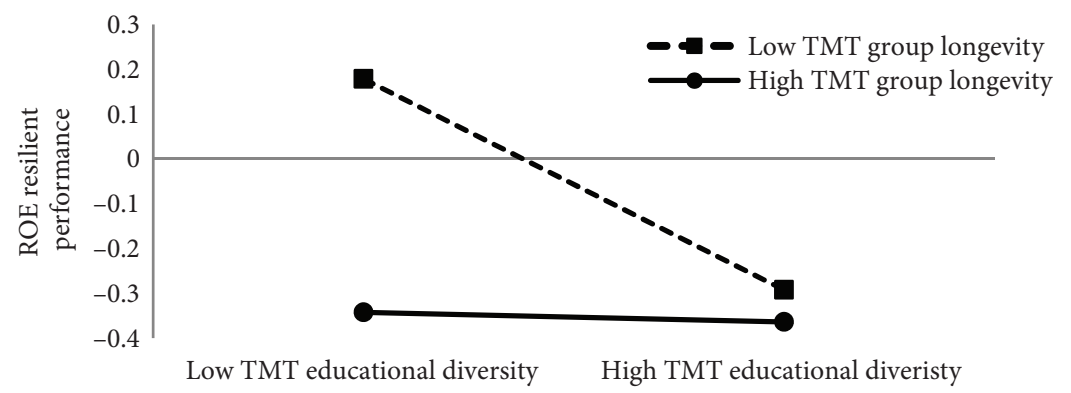

Note:

Simple slope analysis

\begin{tabular}{|l|c|c|c|}
\hline & Gradient of slope & t-value of slope \\
\hline Low TMT group longevity & -0.24 & -2.32 & ${ }^{*}$ \\
\hline High TMT group longevity & -0.01 & -0.10 & \\
\hline${ }^{\dagger} \mathrm{p}<0.1 ;{ }^{*} \mathrm{p}<0.05 ;{ }^{* *} \mathrm{p}<0.01 ;{ }^{* *} \mathrm{p}<0.001$ & \\
\hline
\end{tabular}

Figure 2. Interaction effect of TMT educational diversity and TMT group longevity on ROE resilient performance

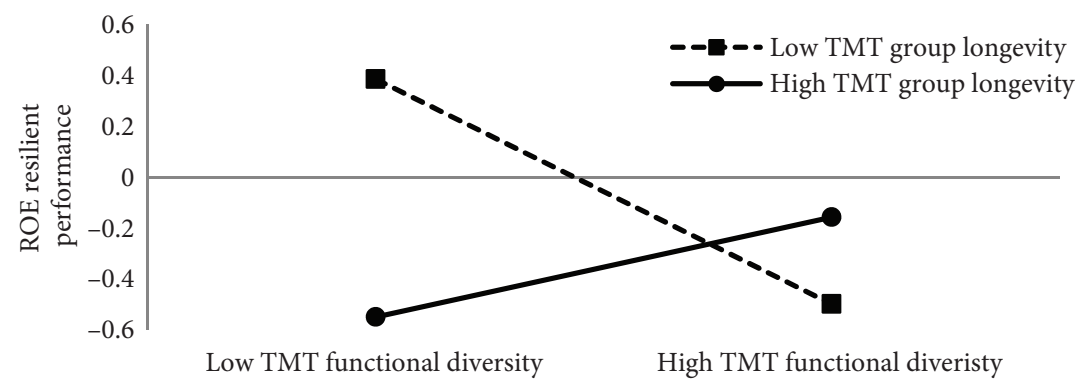

Note:

Simple slope analysis

\begin{tabular}{|l|c|c|l|}
\hline & Gradient of slope & t-value of slope \\
\hline Low TMT group longevity & -0.44 & -4.21 & ${ }^{* *}$ \\
\hline High TMT group longevity & 0.20 & 1.83 & ${ }^{\dagger}$ \\
\hline${ }^{\dagger} \mathrm{p}<0.1{ }^{*} \mathrm{p}<0.05{ }^{* *} \mathrm{p}<0.01 ;{ }^{* * *} \mathrm{p}<0.001$ \\
\hline
\end{tabular}

Figure 3. Interaction effect of TMT functional diversity and TMT group longevity on ROE resilient performance 
high-stakes decisions in a timely manner and share risks collectively. The positive perception of similarities among executives in a newly formed TMT strengthens a psychological safety climate. A high-level psychological safety climate in a TMT facilitates timely decision-making and allows for collective risk taking.

This research joins Cannella, Park, and Lee (2008, p. 772) in arguing that "for a TMT to realize its full potential, its structure (in terms of diversity) needs to be matched to the external (environmental) context in which it is embedded." The empirical results suggest two major critical insights. First, the empirical evidence supports the argument of the crucial role that TMT job-related diversity plays in dynamic environments (Naranjo-Gil et al., 2008). This study examined two types of TMT job-related diversity that have been widely discussed in the literature and revealed that in abruptly dynamic environments, the negative effects of these TMT job-related diversity types prevail over the positive effects. When facing a sudden shock from environmental dynamism, a TMT with a diversified educational and functional background requires a deliberate attempt to enhance its diverse knowledge-based decision making (Bui, Baruch, Chau, \& He, 2015; Zollo \& Winter, 2002). The results of this study suggest that managerial cognitive hurdles that result from TMT members having diversified educational and functional backgrounds are augmented when top executives sense a crisis induced by sudden and substantial environmental dynamism (Menz, 2012). This suggestion warrants further investigation, especially regarding the role of sense-of-crisis in triggering discord in collective decision making among executives with diversified job-related backgrounds (Valackiene \& Virbickaite, 2011).

Second, this study's empirical results highlighted the critical role of TMT group longevity in weakening or reversing the negative effects of TMT educational and functional diversity on a firm's resilient performance in abruptly dynamic environments. The role of TMT group longevity has been underexplored in the literature (Boerner et al., 2011). This study revealed that when TMT member executives have worked together for a long time, the positive effect of TMT functional diversity outweighs the negative effect, and the negative effect of TMT educational diversity is weakened. Heavey and Simsek (2017) suggest that the extent to which cognitive hurdles originating from diversified educational background can be overcome differs from the extent to which cognitive hurdles resulting from diversified functional background can be overcome. This study echoes this view by revealing that when TMT group longevity is increased, the negative effect of TMT functional diversity can be overcome, whereas the negative effect of TMT educational diversity can only be weakened.

The robustness of the result of the ROE resilient performance model was further evaluated by conducting supplemental analyses on the ROS and the ROA resilient performance models. The results of the ROS resilient performance model and those of the ROA resilient performance model are presented in Appendix A and B, respectively. Although the results diverged slightly, the authors considered the ROE resilient performance model adequate for the study's research context because the index of ROE reflects a firm's capability to generate returns for shareholders by appropriating the resources available, including restructuring debts and recapitalizing, during the time of financial crisis. 


\section{Conclusions}

TMT diversity is a double-edged sword for predicting firm performance in dynamic environments. To date, limited research has investigated whether one side of the double-edged sword outweighs the other side in the context of environments characterized by abrupt dynamism. Motivated by this gap in the literature, this study investigated how the two most widely researched TMT job-related diversity types matter in a distinct environmental context characterized by abrupt dynamism and revealed that the negative effect of TMT job-related diversity tends to prevail over the positive effect in such environments. Besides, this study highlights the essential role that TMT group longevity plays in environments of abrupt dynamism. The results of this study highlight the remarkable moderating role that TMT group longevity plays in influencing the relationship between TMT job-related diversity and firm resilient performance.

This study has certain limitations that suggest various directions for future research. First, this study utilized secondary data to investigate how TMT diversity matters in abruptly dynamic environments. This study's results imply that social processes, as embedded in the construct of TMT group longevity, play distinct roles in such environments. Future research might employ a complex quasi-experimental qualitative design to further explore how social processes influence collective decision making among executives with diversified backgrounds in environments of abrupt dynamism. Second, this study adopted a less investigated performance metric, firm resilient performance, in the management field and investigated how TMT diversity influenced firms' resilient performance in a distinct type of environmental dynamism that is characterized by low-frequency, substantial magnitude, and high-degree irregularity of change. Future research might investigate how TMT diversity influences firms' resilient performance under other types of environmental dynamism that involve different characteristics of change frequency, magnitude, and direction. Third, this study utilized a sample of firms in the electronics industry, which is characterized by high managerial discretion and susceptibility to global environmental shocks. Future studies might assess the relationship between TMT diversity and firm resilient performance in other industries. Fourth, this research investigated the moderating role of TMT group longevity and identified its distinct moderating effect. Future research might investigate other contextual factors that could moderate the relationship between TMT diversity and a firm's resilient performance. Additionally, this study controlled for several firm-specific and TMT-related variables. Due to data inaccessibility, this study did not control for the level or the pattern of firm diversification, which may also influence a firm's resilient performance. Future research might investigate the role of firm diversification in such environments. Future research might also adopt the configurational view and explore how configurations of TMT characteristics and firm-specific contextual factors contribute to a firm's resilient performance in abruptly dynamic environments.

Despite the aforementioned limitations, this paper offers several unique contributions to the literature on upper echelons theory. First, this study was undertaken in a naturally quasi-experimental setting that featured abrupt environmental dynamism. Previous upper echelons studies have presented inconsistent empirical evidence concerning the effects of TMT diversity in dynamic environments and have concluded that TMT diversity is a 
double-edged sword. This study focuses on a distinct environmental context characterized by abrupt dynamism, and it reveals that the negative effect of TMT diversity tends to prevail over the positive effect in such environments. Second, this paper acknowledges the essential role that TMT group longevity plays in environments of abrupt dynamism. Relative to other TMT characteristics, limited attention has been paid to the role of TMT group longevity. The results of this study highlight the remarkable moderating role that TMT group longevity plays in influencing the relationship between TMT job-related diversity and firm resilient performance. Third, this study investigates the role of TMT structuring in firms operating in a newly industrialized economy, thus supplementing previous studies that have focused on firms operating in advanced economies.

In addition to the theoretical implications, this study also informs management practice. Since the turn of the 21 st century, enterprises have faced increasingly unpredictable environmental contingencies. Some environmental shocks, such as the global financial crisis, have induced dramatic changes in demand. This study's results demonstrate that structuring TMTs properly can help firms navigate through the difficulties of abruptly dynamic environments.

\section{Acknowledgements}

We are grateful to the editor and the anonymous reviewers for their highly constructive comments on the manuscript. An earlier version of this manuscript was presented at the 2016 Academy of Management Annual Conference. We would like to thank the chairs and participants for their valuable feedback on the earlier version of this manuscript. All shortcomings remain in the responsibility of the authors. The first author acknowledges the funding received from the Taiwan Ministry of Science and Technology.

\section{Funding}

This work was supported by the Taiwan Ministry of Science and Technology under Grant\# MOST 104-2410-H-259-079.

\section{Author contributions}

WHC was responsible for designing the research, collecting and analyzing the data, interpreting the result, and writing the article. YYL was responsible for collecting economic trend data, interpreting the result, and writing the article.

\section{Disclosure statement}

The authors declare that they have no competing financial, professional, or personal interests from other parties that relate to the research described in this paper.

\section{References}


Aiken, L. S., \& West, S. G. (1991). Multiple regression: testing and interpreting interactions. Newbury Park, CA: Sage Publications.

Auh, S., \& Menguc, B. (2005). Top management team diversity and innovativeness: the moderating role of interfunctional coordination. Industrial Marketing Management, 34, 249-261.

https://doi.org/10.1016/j.indmarman.2004.09.005

Bantel, K. A., \& Jackson, S. E. (1989). Top management and innovations in banking: does the composition of the top team make a difference. Strategic Management Journal, 10, 107-124. https://doi.org/10.1002/smj.4250100709

Beneito, P. (2006). The innovative performance of in-house and contracted R\&D in terms of patents and utility models. Research Policy, 35, 502-517. https://doi.org/10.1016/j.respol.2006.01.007

Bharadwaj, A. S., Bharadwaj, S. G., \& Konsynski, B. R. (1999). Information technology effects on firm performance as measured by Tobin's Q. Management Science, 45, 1008-1024. https://doi.org/10.1287/mnsc.45.7.1008

Boerner, S., Linkohr, M., \& Kiefer, S. (2011). Top management team diversity: positive in the short run, but negative in the long run. Team Performance Management, 17, 328-353. https://doi.org/10.1108/13527591111182616

Bricongne, J., Fontagne, L., Gaulier, G., Taglioni, D., \& Vicard, V. (2012). Firms and the global crisis: French exports in the turmoil. Journal of International Economics, 87, 134-146. https://doi.org/10.1016/j.jinteco.2011.07.002

Bui, H. T., Baruch, Y., Chau, V. S., \& He, H. W. (2015). Team learning: the missing construct from a cross-cultural examination of higher education. Asia Pacific Journal of Management, 33, 29-51. https://doi.org/10.1007/s10490-015-9426-Z

Cannella Jr., A. A., Park, J., \& Lee, H. (2008). Top management team functional background diversity and firm performance: examining the roles of team member collocation and environmental uncertainty. Academy of Management Journal, 51, 768-784. https://doi.org/10.5465/AMR.2008.33665310

Carpenter, M. A. (2002). The implication of strategy and social context for the relationship between top management team heterogeneity and firm performance. Strategic Management Journal, 23, 275-284. https://doi.org/10.1002/smj.226

Carpenter, M. A., Geletkanycz, M. A., \& Sanders, W. G. (2004). Upper echelons research revisited: antecedents, elements, and consequences of top management team composition. Journal of Management, 30, 749-778. https://doi.org/10.1016/j.jm.2004.06.001

Certo, S. T., Lester, R. H., Dalton, C. M., \& Dalton, D. R. (2006). Top management teams, strategy and financial performance: a meta-analytic examination. Journal of Management Studies, 43, 813-839. https://doi.org/10.1111/j.1467-6486.2006.00612.x

Chang, M. C., Wang, Y. H., Hung, J. C., \& Sun, C. (2015). R\&D, patent arrangements, and financial performances: evidence from Taiwan. Periodica Polytechnica Social and Management Science, 23, 25-40. https://doi.org/10.3311/PPso.7967

Chau, V. S., Thomas, H., Clegg, S., \& Leung, A. S. M. (2012). Managing performance in global crisis. British Journal of Management, 23, S1-S5. https://doi.org/10.1111/j.1467-8551.2012.00825.x

Chung, C., \& Luo, X. (2013). Leadership succession and firm performance in an emerging economy: successor origin, relational embeddedness, and legitimacy. Strategic Management Journal, 34, 338357. https://doi.org/10.1002/smj.2011

Covin, J., \& Slevin, D. (1989). Strategic management of small firms in hostile and benign environments. Strategic Management Journal, 10, 75-87. https://doi.org/10.1002/smj.4250100107

Daniel, F., Lohrke, F. T., \& Fornaciari, C. J. (2004). Slack resources and firm performance: a metaanalysis. Journal of Business Research, 57, 565-574. https://doi.org/10.1016/S0148-2963(02)00439-3 
Davis, J. L., Bell, R. G., Payne, G. T., \& Kreiser, P. M. (2010). Entrepreneurial orientation and firm performance: the moderating role of managerial power. American Journal of Business, 25, 41-54. https://doi.org/10.1108/19355181201000009

Demsetz, H., \& Lehn, K. (1985). The structure of corporate ownership: causes and consequences. The Journal of Political Economy, 93, 1155-1177. https://doi.org/10.1086/261354

Díaz-fernández, M. C., González-rodríguez, M. R., \& Simonetti, B. (2016). The role played by job and non-job-related TMT diversity traits on firm performance and strategic change. Management Decision, 54, 1110-1139. https://doi.org/10.1108/MD-10-2015-0464

Dolmans, S. A. M., van Burg, J. C., Reymen, I. M. M. J., \& Romme, A. G. L. (2014). Dynamics of resource slack and constraints: resource positions in action. Organization Studies, 35, 511-549. https://doi.org/10.1177/0170840613517598

Eggers, J. P., \& Kaplan, S. (2013). Cognition and capabilities: a multi-level perspective. Academy of Management Annals, 7, 295-340. https://doi.org/10.1080/19416520.2013.769318

Eisenhardt, K. E. (1989). Making fast strategic decisions in high-velocity environments. Academy of Management Journal, 32, 543-576. https://doi.org/10.2307/256434

Eisenhardt, K. E., \& Sull, D. N. (2001). Strategy as simple rules. Harvard Business Review, 79, 107-116. Retrieved from httpss://hbr.org/2001/01/strategy-as-simple-rules

Finkelstein, S., \& Hambrick, D. C. (1996). Strategic leadership: top executives and their effects on organizations. St. Paul, MN: West Publishing Company.

Hambrick, D. C. (2007). Upper echelons theory: an update. Academy of Management Review, 322, 334343. https://doi.org/10.5465/AMR.2007.24345254

Hambrick, D. C., Cho, T. S., \& Chen, M. (1996). The influence of top management team heterogeneity on firms' competitive moves. Administrative Science Quarterly, 41, 659-684. https://doi.org/10.2307/2393871

Hambrick, D. C., \& MacMillan, I. (1985). Efficiency of product R\&D in business units: the role of strategic context. Academy of Management Journal, 28, 527-547. https://doi.org/10.2307/256112

Hambrick, D. C., \& Mason, P. M. (1984). Upper echelons: the organization as a reflection of its top managers. Academy of Management Review, 9, 193-206. https://doi.org/10.5465/AMR.1984.4277628

Harrison, D. A., Price, K. H., \& Bell, M. P. (1989). Beyond relational demography. Academy of Management Journal, 41, 96-107. https://doi.org/10.2307/256901

Hauschild, S., Knyphausen-Auseß, D. Z., \& Rahmel, M. (2011). Measuring industry dynamics: towards a comprehensive concept. Schmalenbach Business Review, 63, 416-454. https://doi.org/10.1007/BF03396827

Heavey, C., \& Simsek, Z. (2017). Distributed cognition in top management teams and organizational ambidexterity: the influence of transactive memory systems. Journal of Management, 43, 919-945. https://doi.org/10.1177/0149206314545652

Hitt, M. A., \& Tyler, B. B. (1991). Strategic decision models: integrating different perspectives. Strategic Management Journal, 12, 327-351. https://doi.org/10.1002/smj.4250120502

Homberg, F., \& Bui, H. T. M. (2013). Top management team diversity a systematic review. Group \& Organization Management, 38, 455-479. https://doi.org/10.1177/1059601113493925

Hough, J. R., \& White, M. A. (2003). Environmental dynamism and strategic decision-making rationality: an examination at the decision level. Strategic Management Journal, 24, 481-489. https://doi.org/10.1002/smj.303

International Monetary Fund. (2018). World economic outlook (April 2018). Retrieved from https:// www.imf.org/external/datamapper

Jarzabkowski, P., \& Searle, R. H. (2004). Harnessing diversity and collective action in the top management team. Long Range Planning, 37, 399-419. https://doi.org/10.1016/j.lrp.2004.07.007 
Judge, W. Q., \& Miller, A. (1991). Antecedents and outcomes of decision speed in different environmental contexts. Academy of Management Journal, 34, 449-463. https://doi.org/10.2307/256451

Kauer, D., Waldeck, T. C. P., \& Schäffer, U. (2007). Effects of top management team characteristics on strategic decision making: shifting attention to team member personalities and mediating processes. Management Decision, 45, 942-967. https://doi.org/10.1108/00251740710762017

Koopmann, J., Lanaj, K., Wang, M., Zhou, L, \& Shi, J. (2016). Nonlinear effects of team tenure on team psychological safety climate and climate strength: implications for average team member performance. Journal of Applied Psychology, 101, 940-957. https://doi.org/10.1037/apl0000097

Kor, Y. T. (2003). Experience-based top management team competence and sustained growth. Organization Science, 14, 707-719. https://doi.org/10.1287/orsc.14.6.707.24867

Lee, H., \& Park, J. (2006). Top management team diversity, internationalization, and the mediating effect of international alliances. British Journal of Management, 17, 195-213. https://doi.org/10.1111/j.1467-8551.2006.00501.x

Li, H., \& Li, J. (2009). Top management team conflicts and entrepreneurial strategy making in China. Asia Pacific Journal of Management, 26, 263-283. https://doi.org/10.1007/s10490-007-9071-2

Li, P. Y., \& Lo, F. Y. (2017). Top management teams' managerial resources and international diversification: the evidence under an uncertain environment. Management Decision, 55, 1999-2017. https://doi.org/10.1108/MD-06-2016-0364

Lin, E., Lin, T. M. Y., \& Lin, B. (2010). New high-tech venturing as process of resource accumulation. Management Decision, 48, 1230-1246. https://doi.org/10.1108/00251741011076762

McKnight, D. H., Cummings, L. L., \& Chervany, N. L. (1998). Initial trust formation in new organizational relationship. Academy of Management Review, 23, 473-490. https://doi.org/10.2307/259290

Menz, M. (2012). Functional top management team members: a review, synthesis, and research agenda. Journal of Management, 38, 45-80. https://doi.org/10.1177/0149206311421830

Milliken, F. J., \& Martins L. L. (1996). Searching for common threads: understanding the multiple effects of diversity in organizational groups. Academy of Management Review, 21, 402-433. https://doi.org/10.5465/AMR.1996.9605060217

Mousa, F. T., \& Chowdhury, J. (2014). Organizational slack effects on innovation: the moderating roles of CEO tenure and compensation. Journal of Business Economics and Management, 152, 369-383. https://doi.org/10.3846/16111699.2013.839476

Murray, A. I. (1989). Top management group heterogeneity and firm performance. Strategic Management Journal, 10, 125-141. https://doi.org/10.1002/smj.4250100710

Naranjo-Gil, D., Hartmann, F., \& Maas, V. S. (2008). Top management team heterogeneity, strategic change and operational performance. British Journal of Management, 19, 222-234. https://doi.org/10.1111/j.1467-8551.2007.00545.x

Nelson, R. R. (1982). The role of knowledge in R\&D efficiency. Quarterly Journal of Economics, 97, 453-470. https://doi.org/10.2307/1885872

Neter, J., Wasserman, W., \& Kutner, M. H. (1985). Applied linear statistical models: regression, analysis of variance, and experimental design. Homewood, IL: R. D. Irwin.

Parola, H. R., Ellis, K. M., \& Golden, P. (2015). Performance effects of top management team gender diversity during the merger and acquisition process. Management Decision, 53, 57-74. https://doi.org/10.1108/MD-03-2014-0141

Pelled, L. H. (1996). Demographic diversity, conflict, and work group outcomes: an intervening process theory. Organization Science, 7, 615-631. https://doi.org/10.1287/orsc.7.6.615

Pelled, L. H., Eisenhardt, K. M., \& Xin, K. R. (1999). Exploring the black box: an analysis of work group diversity, conflict, and performance. Administrative Science Quarterly, 44, 1-28. 
https://doi.org/10.2307/2667029

Prasad, B., \& Junni, P. (2017). Understanding top management team conflict, environmental uncertainty and firm innovativeness: empirical evidence from India. International Journal of Conflict Management, 28, 122-143. https://doi.org/10.1108/IJCMA-02-2016-0006

Sabatino, M. (2016). Economic crisis and resilience: resilient capacity and competitiveness of the enterprises. Journal of Business Research, 69, 1924-1927. https://doi.org/10.1016/j.jbusres.2015.10.081

Sambharya, R. B. (1996). Foreign experience of top management teams and international diversification strategies of U.S. multinational corporations. Strategic Management Journal, 17, 739-746. https://doi.org/10.1002/(SICI)1097-0266(199611)17:9<739::AID-SMJ846>3.0.CO;2-K

Stieglitz, N., Knudsen, T., \& Becker, M. C. (2016). Adaptation and inertia in dynamic environments. Strategic Management Journal, 37, 1854-1864. https://doi.org/10.1002/smj.2433

Taiwan Ministry of Economic Affairs. (2018). Information, professional \& technical services, rental \& leasing survey. Retrieved from https://dmz9.moea.gov.tw/gmweb/investigate/InvestigateEB.aspx?lang=E

Tan, D., \& Mahoney, J. T. (2005). Examining the Penrose effect in an international business context: the dynamics of Japanese firm growth in U.S. industries. Managerial and Decision Economics, 262, 113-127. https://doi.org/10.1002/mde.1212

Valackiene, A., \& Virbickaite, R. (2011). Conceptualization of crisis situation in a company. Journal of Business Economics and Management, 122, 317-331. https://doi.org/10.3846/16111699.2011.575192

Van Geyt, D., Van Cauwenberge, P., \& Vander Bauwhede, H. (2013). The impact of the financial crisis on insider trading profitability in Belgium. Journal of Business Economics and Management, 142, 363-385. https://doi.org/10.3846/16111699.2011.652980

Webber, S. S., \& Donahue, L. M. (2001). Impact of highly and less job-related diversity on work group cohesion and performance: a meta-analysis. Journal of Management, 27, 141-162. https://doi.org/10.1016/S0149-2063(00)00093-3

Weick, K. E., \& Sutcliffe, K. M. (2007). Managing the unexpected: resilience performance in an age of uncertainty. San Francisco, CA: Jossey-Bass.

Yang, L., \& Wang, D. (2014). The impacts of top management team characteristics on entrepreneurial strategic orientation: the moderating effects of industrial environment and corporate ownership. Management Decision, 52, 378-409. https://doi.org/10.1108/MD-03-2013-0140

Yoon, W., Kim, S. J., \& Song, J. (2016). Top management team characteristics and organizational creativity. Review of Managerial Science, 10, 757-779. https://doi.org/10.1007/s11846-015-0175-7

Zollo, M., \& Winter, S. G. (2002). Deliberate learning and the evolution of dynamic capabilities. Organization Science, 13, 339-351. https://doi.org/10.1287/orsc.13.3.339.2780 


\section{APPENDIX A. \\ FINDINGS OF THE ROS RESILIENT PERFORMANCE MODEL}

Appendix A describes the supplemental analyses of the ROS resilient performance model. As reported in Table A1, the relationship between TMT educational diversity and ROS resilient performance was not significant. TMT functional diversity showed a significantly negative effect on the ROS resilient performance $(\beta=-0.24, p<.001)$.

The interaction term involving TMT functional diversity and TMT group longevity was statistically significant $(\beta=0.24, p<.001)$. In order to understand the nature of the interactions, we plotted simple slopes and conducted simple slope analyses. As illustrated in Figure A1, the simple slope analysis illustrated that when TMT group longevity was high, the slope was positive but not significant. However, when TMT group longevity was low, there was a statistically negative association between TMT functional diversity and ROS resilient performance (gradient of simple slope $=-0.48, p<.001$ ). The interaction term involving TMT educational diversity and TMT group longevity was not significant.

Table A1. Results of regression analysis predicting resilient performance

\begin{tabular}{|c|c|c|c|c|c|c|c|c|c|}
\hline \multirow[b]{3}{*}{ Variable } & \multicolumn{9}{|c|}{ Dependent variable: ROS resilient performance } \\
\hline & \multicolumn{3}{|c|}{ Model 1} & \multicolumn{3}{|c|}{ Model 2} & \multicolumn{3}{|c|}{ Model 3} \\
\hline & $\beta$ & $\mathrm{t}$-value & & $\beta$ & t-value & & $\beta$ & t-value & \\
\hline \multicolumn{10}{|l|}{ Control variables } \\
\hline Firm size & -0.30 & -2.43 & * & -0.28 & -2.33 & * & -0.31 & -2.60 & ** \\
\hline Public listing age & 0.41 & 4.69 & $* * *$ & 0.40 & 4.69 & $* * *$ & 0.40 & 4.86 & $* * *$ \\
\hline $\begin{array}{l}\text { Technological } \\
\text { competence }\end{array}$ & 0.00 & 0.03 & & 0.01 & 0.15 & & -0.01 & -0.07 & \\
\hline $\begin{array}{l}\text { Business risk toler- } \\
\text { ance }\end{array}$ & -0.40 & -4.81 & $* * *$ & -0.36 & -4.29 & $* * *$ & -0.38 & -4.72 & $* * *$ \\
\hline TMT size & -0.08 & -0.71 & & -0.08 & -0.79 & & -0.09 & -0.83 & \\
\hline $\begin{array}{l}\text { TMT with interna- } \\
\text { tional experience }\end{array}$ & -0.08 & -1.08 & & -0.01 & -0.11 & & 0.01 & 0.13 & \\
\hline Sub-industry 1 & 0.49 & 2.76 & $* *$ & 0.50 & 2.88 & $* *$ & 0.52 & 3.09 & ** \\
\hline Sub-industry 2 & 0.51 & 2.77 & $* *$ & 0.55 & 3.02 & $* *$ & 0.60 & 3.38 & $* * *$ \\
\hline \multicolumn{10}{|l|}{ Direct effects } \\
\hline $\begin{array}{l}\text { TMT educational } \\
\text { diversity }\end{array}$ & & & & 0.01 & 0.16 & & 0.01 & 0.15 & \\
\hline $\begin{array}{l}\text { TMT functional } \\
\text { diversity }\end{array}$ & & & & -0.20 & -2.74 & $* *$ & -0.24 & -3.31 & $* * *$ \\
\hline $\begin{array}{l}\text { TMT group lon- } \\
\text { gevity }\end{array}$ & & & & -0.17 & -2.27 & * & -0.15 & -2.05 & * \\
\hline \multicolumn{10}{|l|}{ Interaction effects } \\
\hline $\begin{array}{l}\text { TMT educational } \\
\text { diversity x TMT } \\
\text { group longevity }\end{array}$ & & & & & & & 0.02 & 0.26 & \\
\hline
\end{tabular}


End of Table A1

\begin{tabular}{|c|c|c|c|c|c|c|c|c|c|}
\hline \multirow[b]{3}{*}{ Variable } & \multicolumn{9}{|c|}{ Dependent variable: ROS resilient performance } \\
\hline & \multicolumn{3}{|c|}{ Model 1} & \multicolumn{3}{|c|}{ Model 2} & \multicolumn{3}{|c|}{ Model 3} \\
\hline & $\beta$ & t-value & & $\beta$ & t-value & & $\beta$ & t-value & \\
\hline $\begin{array}{l}\text { TMT functional } \\
\text { diversity x TMT } \\
\text { group longevity }\end{array}$ & & & & & & & 0.24 & 3.24 & $* * *$ \\
\hline Constant & -0.36 & -2.68 & & -0.38 & -2.84 & ** & -0.39 & -3.03 & $* *$ \\
\hline F-value & & 6.21 & $* * *$ & & 5.92 & $* * *$ & & 6.17 & $* * *$ \\
\hline $\mathrm{R}^{2}$ & & 0.24 & & & 0.29 & & & 0.34 & \\
\hline Adjusted $\mathrm{R}^{2}$ & & 0.20 & & & 0.24 & & & 0.29 & \\
\hline
\end{tabular}

Note: $\mathrm{n}=168 .{ }^{\dagger} p<.10,{ }^{\star} p<.05,{ }^{* *} p<.01,{ }^{* * *} p<.001$, two-tailed tests.

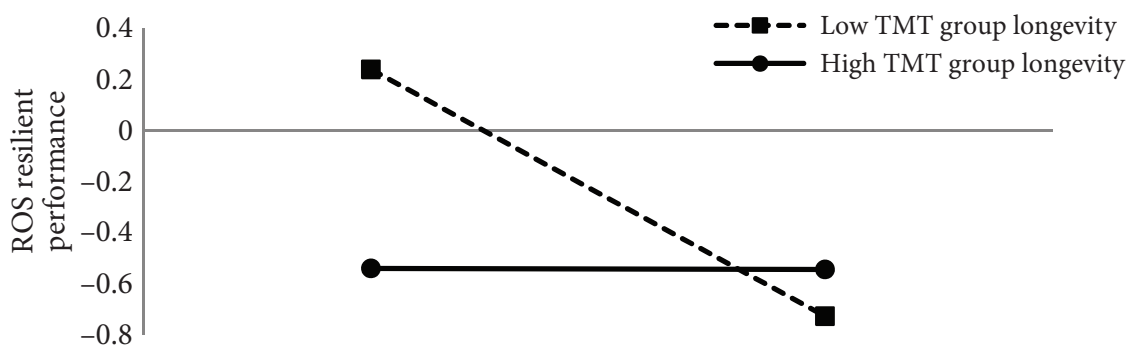

Low TMT functional diversity

High TMT functional diveristy

Figure A1. Interaction effect of TMT functional diversity and

TMT group longevity on ROS resilient performance 


\section{APPENDIX B. \\ FINDINGS OF THE ROA RESILIENT PERFORMANCE MODEL}

Apendix B describes the supplemental analyses of the ROA resilient performance model. As reported in Table B1, the relationship between TMT educational diversity and ROA resilient performance was not significant. The relationship between TMT functional diversity and ROA resilient performance was marginally significant $(\beta=-0.13, p<.1)$. The interaction between ROA resilient performance and TMT functional diversity and educational diversity were both not significant.

Table B1. Results of regression analysis predicting ROA resilient performance

\begin{tabular}{|c|c|c|c|c|c|c|c|c|c|}
\hline \multirow[b]{3}{*}{ Variable } & \multicolumn{9}{|c|}{ Dependent variable: ROA resilient performance } \\
\hline & \multicolumn{3}{|c|}{ Model 1} & \multicolumn{3}{|c|}{ Model 2} & \multicolumn{3}{|c|}{ Model 3} \\
\hline & $\beta$ & $\begin{array}{c}\mathrm{t}- \\
\text { value }\end{array}$ & & $\beta$ & $\begin{array}{c}\mathrm{t}- \\
\text { value }\end{array}$ & & $\beta$ & $\begin{array}{c}\mathrm{t}- \\
\text { value }\end{array}$ & \\
\hline \multicolumn{10}{|l|}{ Control variables } \\
\hline Firm size & -0.31 & -2.53 & $* *$ & -0.31 & -2.51 & * & -0.31 & -2.49 & $* *$ \\
\hline Public listing age & 0.47 & 5.41 & $* * *$ & 0.45 & 5.17 & $* * *$ & 0.45 & 5.14 & $* * *$ \\
\hline Technological competence & -0.24 & -3.19 & $* *$ & -0.24 & -3.06 & ** & -0.23 & -3.01 & $* *$ \\
\hline Business risk tolerance & -0.10 & -1.20 & & -0.11 & -1.25 & & -0.10 & -1.20 & \\
\hline TMT size & 0.14 & 1.34 & & 0.15 & 1.43 & & 0.16 & 1.43 & \\
\hline $\begin{array}{l}\text { TMT with international } \\
\text { experience }\end{array}$ & -0.12 & -1.62 & $\dagger$ & -0.07 & -0.90 & & -0.08 & -0.93 & \\
\hline Sub-industry 1 & 0.16 & 0.91 & & 0.17 & 0.98 & & 0.17 & 0.98 & \\
\hline Sub-industry 2 & 0.10 & 0.57 & & 0.14 & 0.75 & & 0.14 & 0.74 & \\
\hline \multicolumn{10}{|l|}{ Direct effects } \\
\hline TMT educational diversity & & & & -0.02 & -0.31 & & -0.02 & -0.29 & \\
\hline TMT functional diversity & & & & -0.13 & -1.72 & $\dagger$ & -0.13 & -1.65 & $\dagger$ \\
\hline TMT group longevity & & & & 0.02 & 0.24 & & 0.01 & 0.14 & \\
\hline \multicolumn{10}{|l|}{ Interaction effects } \\
\hline $\begin{array}{l}\text { TMT educational diversity } \mathrm{x} \\
\text { TMT group longevity }\end{array}$ & & & & & & & -0.02 & -0.36 & \\
\hline $\begin{array}{l}\text { TMT functional diversity } \mathrm{x} \\
\text { TMT group longevity }\end{array}$ & & & & & & & -0.02 & -0.20 & \\
\hline Constant & -0.11 & -0.79 & & -0.12 & -0.91 & & -0.13 & -0.92 & \\
\hline F-value & & 6.08 & $* * *$ & & 4.72 & $* * *$ & & 3.96 & $* * *$ \\
\hline $\mathrm{R}^{2}$ & & 0.23 & & & 0.25 & & & 0.25 & \\
\hline Adjusted $\mathrm{R}^{2}$ & & 0.20 & & & 0.20 & & & 0.19 & \\
\hline
\end{tabular}

Note: $\mathrm{n}=168 .{ }^{\dagger} p<.10,{ }^{*} p<.05,{ }^{* *} p<.01,{ }^{* * *} p<.001$, two-tailed tests. 